\title{
INFLUENCE OF UNIVERSITY EDUCATION ON THE FORMATION OF THE TAX CULTURE OF THE PUBLIC ACCOUNTANT
}

\author{
William Alberto Pirela Espina \\ Independient investigator. Venezuela \\ williampirela@gmail.com \\ Reception date: 03/15/2021 - Approval date: 03/18/2021 \\ DOI: https://doi.org/10.36995/j.visiondefuturo.2021.26.01.001.en
}

\begin{abstract}
The objective of this work was to analyze the influence of university education in the formation of the tax culture of the public accountant; where the bibliographic review was directed to prominent authors in the area such as: Matteucci (1995), Vizcaíno (2001), Robles (2002), Guaiquirima (2004), Brasvlasky (2005), Gómez (2008) and Coetzee and Oberholzer (2009), among others. Being an investigation under a documentary methodology, a pure bibliographic design, in which the collection of information was carried out through the documentary observation technique. It was concluded that the curricular structure in the university training of the public accountant should include teaching programs oriented to strengthen citizenship values; being important a combined relationship between the bodies of the Tax Administration, private companies and university institutions so that together they contribute to the generation of tax culture in citizens. The future professional has the opportunity to consolidate their commitment to the development of the country, correcting deep-rooted behaviors of tax evasion that have been present to escape from duties to the State; being the public accountant multiplying agent for the strengthening of the tax culture within the organizations and the community.
\end{abstract}

KEY WORDS: Tax culture; Tax Education; Tributes

INTRODUCTION

The vast majority of the constitutions of the countries of the world indicate the obligation that citizens have to collaborate with the satisfaction of public charges of the State through the payment of taxes. This collaboration has not been widely accepted by taxpayers, who seek the advice of the public accounting professional in order to pay the least amount of taxes through tax evasion and avoidance.

Throughout history, the taxpayers of the substantial tax obligation have always had little disposition to comply with this constitutional duty; demonstrating a low level of tax culture that is reflected in the collection levels.

\footnotetext{
"Visión de Futuro" Año 19, Volumen No 26 No 1, Enero - Junio 2022 - Pág 22 - 37 URL de la Revista: http://visiondefuturo.fce.unam.edu.ar/index.php/visiondefuturo/index URL del Documento: https://visiondefuturo.fce.unam.edu.ar/index.php/visiondefuturo/issue/view/22 ISSN 1668 - 8708 - Versión en Línea 
Now, for Velarde (2006), human behavior can be modified to transform undesirable aspects into productive and accepted ones for society; by virtue of which it is necessary to induce the behavior of the citizen to make the decision to voluntarily comply with their tax obligations.

In this sense, it is necessary to deepen the relationship that must exist between the citizen and the State, in order to generate a culture that affects their way of conceiving compliance with tax obligations as a primary duty in accordance with the values of a society based on the supremacy of the common good.

In this regard, Velarde (2006), affirms that developing this culture is not an easy task, since it requires a convergence of control policies with those of an educational nature; Before which it is essential to promote the tax culture in future taxpayers, starting from university education; which can be conceived as a solution aimed at reducing tax evasion originated as a consequence of the low level of tax culture in the population.

Therefore, it is necessary to promote a tax culture from an early school age, where each student has the opportunity to receive and speak about the values and commitment that they have as a citizen in helping the State with public charges; and thus to be able to correct deep-rooted behaviors of tax evasion that have been continuously present in a significant number of individuals to escape from tax duties.

Undoubtedly, that university education plays a fundamental role in the public accounting professional who is called to be a multiplier agent in his community and in his professional field as a fundamental piece for the promotion of the tax culture.

By virtue of this, it is necessary for universities to include teaching programs in tax culture to strengthen citizenship values in students, who will be future taxpayers; but not only to promote knowledge, but also to carry out tax ethics practice in their future professional environment.

Although it is true that the governments of the countries have the urgent need to resize the sources of income, considering an improvement in internal tax collection and the reduction of tax evasion, it is necessary to change the vision about the taxpayer and encourage culture tax so that they voluntarily collaborate to solve the financing needs of public expenditures.

Therefore, the tax culture must be based on values that tend to the common good, and from the university educational system, it must try to make teachers and students aware of the constant practice of these values; making it necessary for all citizens to strengthen their tax culture and thus understand that taxes are resources collected by the State in its capacity

\footnotetext{
"Visión de Futuro" Año 19, Volumen No 26 N 1, Enero - Junio 2022 - Pág 22 - 37 URL de la Revista: http://visiondefuturo.fce.unam.edu.ar/index.php/visiondefuturo/index

URL del Documento: https://visiondefuturo.fce.unam.edu.ar/index.php/visiondefuturo/issue/view/22

ISSN 1668 - 8708 - Versión en Línea

E-mail: revistacientifica@fce.unam.edu.ar
} 
as administrator, but in reality they will be paid to the community in public goods and services to improve their quality of life.

In this regard, there are theoretical positions that affirm that the levels of tax culture occur before governments that stand out for the lack of transparency in the management of public resources, to this is added the possible breach of the Code of Ethics of the Public Accountant, for what which addresses the economic impact it causes for every country and the commitments that accountants must fulfill before society, from a moral and ethical perspective,

Based on these considerations, the main objective proposed in this research was to analyze the influence of University Education in the formation of the tax culture of the public accountant.

On the other hand, in many investigations it is common for the meta-analysis methodology to be applied as an important tool to respond to a problem raised. A metaanalysis involves a quantitative synthesis of the accumulated evidence on a previously defined research question; whose answer will be based on the information contained in previously published studies (primary studies).

For Botella and Sánchez-Meca (2015), meta-analysis is a methodology for the quantitative analysis of reviews of the scientific literature on a specific question; One way to assess the quality of a meta-analysis by the researcher is to fixate on the extent that it is precise, objective and replicable. These features of the meta-analysis allow the investigator to obtain a pooled estimate of the effect size and to assess the heterogeneity observed in a field of study; to help you formulate new hypotheses that incorporate the role of variables that have not been considered until now.

However, this methodology has weaknesses such as the problem of heterogeneity (real threat to the validity of the researcher's conclusions) and publication bias (higher probability of publication for significant studies).

Based on the above, this research work was not based on the meta-analysis of the tax culture of the public accountant, but was based on a systematic review of the existing documentary on the subject, in this way the researcher identified and evaluated studies of the same type and with a common objective, such as analyzing the influence of University Education in the formation of a tax culture in public accountants.

Reason why the research was carried out under a documentary type methodology, with a pure bibliographic design, defined by De Pelekais, Finol; Neuman and Belloso (2007), as the systematic process in the search for information, selection, reading, recording, organization, description and interpretation of data extracted from existing documentary

\footnotetext{
"Visión de Futuro" Año 19, Volumen No 26 N 1, Enero - Junio 2022 - Pág 22 - 37

URL de la Revista: http://visiondefuturo.fce.unam.edu.ar/index.php/visiondefuturo/index

URL del Documento: https://visiondefuturo.fce.unam.edu.ar/index.php/visiondefuturo/issue/view/22

ISSN 1668 - 8708 - Versión en Línea

E-mail: revistacientifica@fce.unam.edu.ar
} 
sources around a problem, in order to find answers to the questions posed in any area of knowledge.

The bibliographic review was carried out by consulting international electronic databases such as Dialnet, Jstore, Redalyc, Scielo and Google Academic; from where pertinent information was extracted, between the years 1990 to 2020; through the application of the documentary observation technique, which, according to Abreu (2016), consists of an operational process to obtain and record in an organized way the information present in books, scientific journals, newspapers, scientific reports, published articles, among others.

In each database, six (6) articles were selected with which an Excel sheet was created, detailing the following fields: data, research problem, objectives, results and conclusions. Then they were grouped into two thematic axes: the university education of the public accountant and the formation of a tax culture, later an analysis of each one was carried out, identifying the most important and relevant. To conclude, the similarities, concordances and contradictions between the authors were determined to finally argue in relation to the identified situation.

Through the study, a State of the Art was built in which the influence of University Education in the formation of a tax culture in the public accountant was analyzed. For this purpose, the aforementioned databases were explored, focusing on the subjects investigated to carry out a detailed analysis of the subject.

Likewise, in order to create knowledge, the pioneering authors in tax culture, whose postulates are still in force, were consulted, such as: Matteucci (1995), Vizcaíno (2001), Robles (2002), Guaiquirima (2004), Brasvlasky (2005 ), Gómez (2008) and Coetzee and Oberholzer (2009), among others.

\section{DEVELOPMENT}

The State is responsible for the search for the common good of society, however, for them it needs citizens to contribute with the payment of taxes to be able to reinvest them for the benefit of the community, becoming a moral duty.

For Vizcaíno (2001), these obligations of the State and citizens suppose an unequivocal conception of man as a social being and not as a mere individual subject disconnected from society. Taxes are the collaboration fee that every citizen must pay for the benefits he receives from the State and for the co-responsibility that he must exercise in relation to the common good. However, for the State to fulfill its main purpose in relation to taxes, certain conditions are necessary:

- The tax system is fair.

\footnotetext{
"Visión de Futuro" Año 19, Volumen No 26 No 1, Enero - Junio 2022 - Pág 22 - 37

URL de la Revista: http://visiondefuturo.fce.unam.edu.ar/index.php/visiondefuturo/index

URL del Documento: https://visiondefuturo.fce.unam.edu.ar/index.php/visiondefuturo/issue/view/22

ISSN 1668 - 8708 - Versión en Línea

E-mail: revistacientifica@fce.unam.edu.ar
} 
- Has the adequate material infrastructure so that the collection can be carried out to all those who must pay, avoiding, as much as possible, evasion.

- The uses made by the State are effectively for the common good.

Undoubtedly, for the State to be able to comply with its constitutional obligation to ensure the common good and provide the population with the basic services that it requires, it needs resources whose main source is the taxes paid by the taxpayers. Your payment can be channeled by the State using its coercive power contained in the laws or by appealing to the reason of the citizen, which is manifested through a tax culture with solid foundations, which shows the close relationship that exists between the payment of taxes and the level of tax culture of citizens.

It is noteworthy that, at the university level, proposals have been made to include aspects in the training of future professionals that allow them to help raise the level of tax culture; proposing pedagogical strategies aimed at promoting the tax culture in students.

Robles (2002) explains that students have a low knowledge of tax aspects, which is why he proposes to include in educational programs those important aspects of current tax legislation, such as: tribute, tax classes, tax subjects, the legal-tax relationship, legal-tax obligation, among others; to instill in students a civic and tax awareness and achieve the objective of the Tax Administration, which is to modify the taxpayer's behavior.

For any professional, the university represents the place where they learn the set of knowledge that will allow them to start in the exercise of a profession with efficiency, which will allow them to advance in the knowledge of a field of knowledge, in a way and in such a way that can undertake research, specialization and deepening of the same. However, it is not so obvious that the university is the place where ethical principles and citizenship are learned.

Consequently, in the current sociocultural context, the university environment is a learning space, both professional, cultural, human, and therefore ethical and moral. In this sense, it should be considered as an error of perception to waste this function, since it is a duty to promote the pedagogical power of the university in relation to the learning and formation of these values in students, taking into account that said institution has the will to public service.

In this area, the university has an ethical function whose dimension can be identified in today's society, in the following aspects:

- deontological training related to the exercise of the different professions,

- citizenship and civic training of its students; $y$

\footnotetext{
"Visión de Futuro" Año 19, Volumen No 26 No 1, Enero - Junio 2022 - Pág 22 - 37

URL de la Revista: http://visiondefuturo.fce.unam.edu.ar/index.php/visiondefuturo/index

URL del Documento: https://visiondefuturo.fce.unam.edu.ar/index.php/visiondefuturo/issue/view/22

ISSN 1668 - 8708 - Versión en Línea

E-mail: revistacientifica@fce.unam.edu.ar
} 
- human, personal and social training that contributes to the ethical and moral excellence of future professionals

Certainly, these dimensions are accepted as a sign or indicator of quality; admitted as a need and a challenge in which they must converge between them and these levels are typical of other levels of the educational system; but seeking to be integrated into the mission and vision of university careers.

Within this framework, the objective of any quality university with a philosophy of public service is to make society more dignified, turning its students into excellent professionals and increasingly cultured and critical citizens. That is why university personnel at all levels bear in mind, permanently, that these results are achieved when living in contexts where the search for truth is rigorously practiced; through argumentation, dialogue and open deliberation; avoiding dogmatisms and fundamentalisms, in social interaction and in collaboration with others.

According to the above, the changes in perspective in relation to the teaching culture pose university training not only in the professional aspect but also as a citizen; in this sense, there are reasons to consider that a quality university education cannot separate citizen behavior from the professional future.

In this sense, the current concept of university education must have the objective of social cohesion, and not only of competitiveness; which must be derived from research on moral development and ethical learning. These aspects are related to each other and their objective is the construction of citizenship committed to social welfare. During the university training period, rigor should not be lacking in favoring attitudes that invite the deepening of knowledge about those issues that affect the participation and decision-making of students in both public and private contexts; nor in those that can foreseeably affect them as professionals and citizens in the process of training.

By virtue of the above, it is convenient to predict the accumulation of knowledge and skills that the future university professional will need in any area of knowledge, so that their participation in decision-making is adequate, pertinent and grounded, when required as a reference. This task requires the incorporation of elements for reflection, procedures for praxis and a series of attitudes and values that facilitate their performance based on criteria of correctness and university veracity.

In this regard, the career of public accounting is a profession that entails a technical, social and therefore tax commitment, as well as analytical components that promote its good function within organizations and society, therefore, the training of Future professionals must

\footnotetext{
"Visión de Futuro" Año 19, Volumen No 26 N 1, Enero - Junio 2022 - Pág 22 - 37 URL de la Revista: http://visiondefuturo.fce.unam.edu.ar/index.php/visiondefuturo/index

URL del Documento: https://visiondefuturo.fce.unam.edu.ar/index.php/visiondefuturo/issue/view/22

ISSN 1668 - 8708 - Versión en Línea

E-mail: revistacientifica@fce.unam.edu.ar
} 
be aimed at an interdisciplinarity of knowledge that contributes to the effective development of their skills.

However, one of the concerns that arises on the part of newly graduated accounting professionals is that their role within organizations forces them to perform with arduous knowledge of the topics of interest to companies, without neglecting the responsibilities that as a citizen influence their professional performance.

In other words, many have been the research works consulted that are related to the role of university education in the formation of a tax culture in the public accountant; However, the vast majority focus their attention on the professional and do not consider other variables that directly affect the quality of their training, such as: changes in the curriculum, the preparation of teachers to lead the teaching process -learning in Higher Education, and methodological work based on the citizen training of the professional future.

For Coetzee and Oberholzer (2009), their main objective is to describe the training that Public Accounting students in South Africa are given for the purposes of tax knowledge when they enter an internship contract, additionally they seek to identify the level of satisfaction of the students. These authors conclude that although the academic training of accountants for the most part is adequate, upon reaching the practices they were not capable enough to perform the tasks.

Now, the contribution it makes to this research is the need for program developers and educators to examine the practicality of the current content offered by universities, in relation to the needs of the world of work, which overcome the need for knowledge on topics tax, analytical, humanistic, technical, among others, that look after organizations and society in general.

Likewise, the work of Herrera (2014), aimed to identify the conception of the tax culture in Colombian higher education institutions, as well as to evaluate procedures and controls that may be useful for them. To achieve these objectives, he used the qualitative paradigm, which is characterized by the conceptualization of tax management, as a constructed reality that is governed by social laws that relate to the State and Society, concluding that strategies should be embraced to encourage the tax culture from early ages, in order to promote the common good and achieve the training of responsible individuals committed to good tax practices.

On the other hand, the research work of Aragonés, Lópaz, and Campos (2015), had the purpose of making known the little tax awareness and the low morale that Spanish society has due to the absence in training in schools and Universities on these topics, conclude that professors have a high level in ethics, but focus on teaching "numbers", they

\footnotetext{
"Visión de Futuro" Año 19, Volumen No 26 N 1, Enero - Junio 2022 - Pág 22 - 37

URL de la Revista: http://visiondefuturo.fce.unam.edu.ar/index.php/visiondefuturo/index

URL del Documento: https://visiondefuturo.fce.unam.edu.ar/index.php/visiondefuturo/issue/view/22

ISSN 1668 - 8708 - Versión en Línea

E-mail: revistacientifica@fce.unam.edu.ar
} 
consider that they can provide more ethical value where they encourage students to combat tax fraud with tax awareness.

Other authors such as Aguilar, Ceballos, Restrepo and Gómez (2015) emphasize the training models that are required for public accountants to meet the needs of the State, organizations, the community and families, using a hermeneutical research method, in which they concluded that the educational system is flawed since it does not respond correctly to the socioeconomic needs of the country, presenting gaps at the professional level.

For Silvestri and Silvestri (2015), the importance of joint work between institutional media, private companies and university institutions for joint action on learning strategies for tax culture in Venezuelan university education; concluding that content related to State tax resources and their relationship with public needs are necessary.

The authors Yaguache-Aguilar, Pardo-Cueva and Espejo-Jaramillo (2018), developed a work whose purpose was to disseminate the applied strategies and the achievements of the Particular Technical University of Loja (UTPL) in Mexico and the promotion of Support Nuclei Accountant and Fiscal (NAF) from the Academy, which has generated enrichment of knowledge for students, teachers and officials of the Internal Revenue Service (SRI) and especially of the sectors that have been intervened to create competencies in the fulfillment of their tax obligations.

These authors consider it necessary to continue with the Accounting and Fiscal Support Centers (NAF), providing tax advice free of charge that allows the general public to know the importance of taxes for the development of the country; concluding that to promote the tax culture requires joint work between the tax administration, academia and society.

Montoya and Castañeda (2020) point out that in university institutions knowledge is not perceived in the best way, due to lack of updating of the teachers and the content of the subjects, in addition to the little practice in the applicability of the tax part and Regarding the understanding of the essence of this that helped to assimilate the norm even if it is in continuous change.

For the aforementioned, one of the important aspects to consider in the training of future public accounting professionals is represented by tax education, which aims to convey opinions, values and attitudes regarding the tax responsibility of citizens. Its objective is not to teach content of an academic nature, where teams of facilitators must work on it as a matter of citizen responsibility, since it represents an instrument of equality, opportunities, social inclusion and the formation of human capital with moral principles and ethical values.

According to Solórzano, (2013), tax education must start from the first educational levels and represents a strategy par excellence for the formation of a tax awareness and 
culture that implies assuming compliance with tax obligations as a necessary counterpart to the legitimate exercise of rights civic.

It is for this reason that a higher level of tax awareness regarding tax compliance, together with a perception of effective risk due to contempt, will allow countries to reduce the high rates of evasion, informality and smuggling that exist.

However, compliance with tax obligations may be sufficient to achieve the objectives of tax collection, conditional on the perception of risk that taxpayers have, and above all the capacity of inspection and sanction of the Tax Administration of the countries.

In order to develop a moral and sense of commitment in the taxpayer, it is necessary to generate an awareness that establishes the framework of the actions and guidelines to be followed, which help in the progress and process of their search. Likewise, government actions must be subject to being carried out with total transparency and efficiency in the management of public resources to encourage taxpayers to voluntarily comply with their tax obligations.

For Matteucci (1995), tax awareness is the internalization in individuals of the tax duties set by the laws, so that they are complied with voluntarily and in turn that this compliance generates a common benefit for the society of which they are part.

In this sense, Guaiquirima (2004), asserts that the formation of tax awareness is not an easy job, it requires time, since it implies a continuous process of learning and assimilation by society, being necessary the development, discernment and commitment of each and every one of the Tax Administration officials in supporting the management that is carried out.

For this purpose, it is necessary to develop a tax culture that allows citizens to conceive tax obligations as a substantive duty, in accordance with democratic values, which is not an easy task, since it requires the convergence of control policies with policies of a nature. educational.

For Gómez (2008), tax culture is the level of knowledge that individuals in a society have about the tax system and its functions. It is necessary for all citizens of a country to have a strong tax culture so that they can understand that taxes are resources collected by the State as an administrator, but in reality these resources belong to the population, therefore, it is the obligation of the State return them in public goods and services.

Regarding the tax culture, Golía (2003) affirms that it is the set of knowledge, assessments and attitudes related to taxes, as well as the level of belief regarding the duties and rights that derive for the active and passive subjects of that relationship.

\footnotetext{
"Visión de Futuro" Año 19, Volumen No 26 N 1, Enero - Junio 2022 - Pág 22 - 37

URL de la Revista: http://visiondefuturo.fce.unam.edu.ar/index.php/visiondefuturo/index

URL del Documento: https://visiondefuturo.fce.unam.edu.ar/index.php/visiondefuturo/issue/view/22

ISSN 1668 - 8708 - Versión en Línea

E-mail: revistacientifica@fce.unam.edu.ar
} 
In the same way, Vanegas (2016) defines it as the set of information and the level of knowledge that a given country has about taxes, as well as the set of perceptions, criteria, practices and attitudes that society has regarding taxation.

Likewise, Andrade (2012) points out that the tax culture is the set of values, beliefs and attitudes, shared by a society regarding taxation and the laws that govern it, which leads to permanent compliance with tax duties.

In consideration of the authors Díaz, Cruz and Castillo (2017), the tax culture should be understood as a set of values, knowledge and attitudes shared by the members of a society regarding taxation and the observance of the laws that govern it, that lead to the permanent and voluntary fulfillment of tax duties based on reason, trust and the affirmation of the values of personal ethics, respect for the law, citizen responsibility and social solidarity, both of taxpayers and officials of the the different tax administrations.

Also, Bonilla (2014) defines it as the set of actions that seek to convince citizens of the possibility, necessity and convenience of fair taxation. The tax culture assumes the commitment to educate citizens on tax issues, which promote compliance with the responsibilities of the taxpayer, aware of the proper use of public assets.

For Gómez, Jiménez, and Martner (2017), it is important to prioritize a tax culture in which evaders are effectively penalized and, furthermore, it is understood that tax revenues constitute the fundamental basis for financing the essential functions of a modern State.

Méndez (2004) and Armas (2009) state that the tax culture is a set of values, knowledge and attitudes shared by the members of a society regarding taxation and compliance with the laws that govern it, this translates into behavior manifested in the permanent and voluntary fulfillment of tax duties based on reason, trust, the affirmation of personal ethical values, the duties and rights that derive for active and passive subjects, respect for the law, citizen responsibility and solidarity social, both of the taxpayers, and of the officials of the different tax administrations, in order to create a civic-tax awareness and thus avoid tax evasion.

Within this framework, Cortázar (2005) alleges that contents such as the social assessment of tax non-compliance respond, to a large extent, to the collective representations around the Tax Administration, the role of the State and its relationship with citizens, therefore, it is necessary to act on these representations. Indeed, the tax culture is shaped by a heterogeneous set of reference information, practices and events linked to each other by the way they are articulated around a dominant representation.

Consequently, it is conceived that the tax culture comprises a set of values, beliefs or social representations that individuals attribute to the tax action of the State, connoting their

\footnotetext{
"Visión de Futuro" Año 19, Volumen No 26 N 1, Enero - Junio 2022 - Pág 22 - 37

URL de la Revista: http://visiondefuturo.fce.unam.edu.ar/index.php/visiondefuturo/index

URL del Documento: https://visiondefuturo.fce.unam.edu.ar/index.php/visiondefuturo/issue/view/22

ISSN 1668 - 8708 - Versión en Línea

E-mail: revistacientifica@fce.unam.edu.ar
} 
behavior as a taxpayer within society, being interesting for the purposes of this work to consider the Cortázar's approaches (2005) as he adjusts to consider it as formative in the educational field.

According to the above, it can be affirmed that the tax culture does not mean the level of knowledge that a person has about their tax responsibilities and their corresponding action; Rather, the tax culture is directed towards the construction of taxes from the combination of information. In this sense, it is important that the tax culture begins at school and continues at the university level, which implies educational work in the proper use of public assets.

Consequently, the tax culture is identified with the voluntary fulfillment of tax duties and obligations by the taxpayer and not with the implementation of strategies to increase tax collection and not under pressure, for fear of the sanctions established in the tax regulations. penalties.

For this reason, this lack of tax education is reflected in a low level of tax awareness and culture, which makes citizens fail to comply with the regulations, even though they know their tax obligations; ignoring and not making your payment.

In this regard, some taxpayers evade compliance with their tax obligations in order to take advantage of this unpaid money, causing the nation to increase tax burdens, inequality and imbalance of public finances.

Therefore, the tax culture is of individual content, and consists of the belief that each person or member of a social group has that the payment of taxes constitutes a fair, essential and beneficial contribution when used to satisfy the needs of the community of which they are part.

Gómez (2008) points out that tax evasion is the lack of compliance with obligations by taxpayers. This lack of compliance can lead to an effective loss of income for the National Treasury; Being that it originates from a conscious and deliberate conduct of the taxpayer of the legal-tax relationship, being a situation of importance in the laws of each country.

In this sense, Cortázar (2005), argues that the fight against tax evasion is currently a topic of great importance on the political agendas of all countries, due to its high impact on economic stability and development strategies, Therefore, an effort is necessary to control compliance with tax obligations and generate a credible risk in the event of non-compliance, being essential to develop a tax culture that allows citizens to conceive tax obligations as a substantive duty.

The authors Morales, Ruiz and Ycaza (2009), affirm that tax evasion is one of the greatest phenomena that directly affects the tax system of a country, the lack of payment of

\footnotetext{
"Visión de Futuro" Año 19, Volumen No 26 N 1, Enero - Junio 2022 - Pág 22 - 37

URL de la Revista: http://visiondefuturo.fce.unam.edu.ar/index.php/visiondefuturo/index

URL del Documento: https://visiondefuturo.fce.unam.edu.ar/index.php/visiondefuturo/issue/view/22

ISSN 1668 - 8708 - Versión en Línea

E-mail: revistacientifica@fce.unam.edu.ar
} 
taxes, fees and contributions not only erodes the income of the State, but deteriorates the structure and economy of a country, causing a harmful effect on society.

For Mendoza (2013), few strategies have been established at the university level to promote learning in matters of tax culture, which must constitute that set of means designed to generate knowledge, values and social representations that lead citizens to value as suitable the process of fulfilling its tax duties for the good of the community, considering the social consideration of the tribute, in terms of justice and equality.

To this end, the cultural context where future university professionals are trained suggests educational actions that may converge with those of the Tax Administration, in order to modify those perceptions that reinforce non-compliance, thus consolidating the social legitimacy of tax examination, representing the possibility of generating educational strategies that promote a tax culture, which is a fundamental aspect in achieving these objectives and their impact in the area of accounting professional training.

Due to this, the systematization of the proposed contents that should be considered in the learning strategies of the tax culture in higher education is essential, in order to specifically define all the concepts and theories that are considered relevant for the formation of the university population.

By virtue of this, talking about tax education transcends as a new practice that is oriented towards the development of values, attitudes and skills, elements that are intended to stimulate in university students a critical judgment that allows aligning their relationship with the State and with other citizens in tax matters in the context of democratic coexistence.

According to the above, one of the objectives that university education should pursue is to create awareness about the importance of paying taxes, which allows the State to obtain the resources to satisfy public needs, in addition to insisting on the promotion of values ethical and moral, based on a constant process of communication that allows to disseminate all the information related to taxes, and develop and execute educational strategies that allow university students to train that culture of civic duty.

It should be noted that the educational system must seek a development in the individual of a concept of fiscal awareness, which allows through the reinforcement of those learned at home to internalize in the student the fulfillment of the obligations and duties that this has, in regarding the contribution of public spending; and in this way generate a strong tax morale with democratic values and principles, thus building a civic-tax culture in society.

In other words, university education and tax culture are closely linked, since teachers must seek through education to make students aware of the importance of contributing to the

\footnotetext{
"Visión de Futuro" Año 19, Volumen No 26 N 1, Enero - Junio 2022 - Pág 22 - 37

URL de la Revista: http://visiondefuturo.fce.unam.edu.ar/index.php/visiondefuturo/index

URL del Documento: https://visiondefuturo.fce.unam.edu.ar/index.php/visiondefuturo/issue/view/22

ISSN 1668 - 8708 - Versión en Línea

E-mail: revistacientifica@fce.unam.edu.ar
} 
payment of taxes from a perspective of justice and equity. Education is presented as the most powerful means to transform the behavior and thinking of individuals.

For Brasvlasky (2005), recently graduated professionals have to opt for complementary studies that strengthen their knowledge in tax matters, since what is perceived during their academic training results in many cases of difficult application in professional practice, implying that it is What is learned in higher education institutions is very different from what they have to perform at work, so they feel empty both in concepts and in the way of developing.

Therefore, it is required that the general population receive knowledge on the subject and understand the importance of their tax responsibilities, as an effective means for the State to meet the needs of the group, that is, that citizens with the support of professionals in public accounting become aware of its meaning, as well as the need to contribute to it by complying with the tax duties established by the national constitution and the laws.

\section{CONCLUSION}

Through the formation of a tax culture, it is intended that the individuals of society involved in the process become aware of the constitutional duty they have to contribute to the State, in order to have the necessary resources for it to comply. with the duty to guarantee effective and efficient public services to citizens.

In this sense, future professionals must be individuals capable of facing changing situations in the organizations where they work, which will be linked to the tax knowledge acquired during their training; always focused on their good professional performance.

Therefore, higher education institutions are committed to giving future professionals the necessary tools to develop skills that allow them to merge theory with practice, and thus have autonomy when applying the knowledge acquired during their professional training. , by virtue of which the academic curriculum must be reinvented with a view to improvement, to open spaces that strengthen said skills.

Likewise, content referring to State tax resources and their relationship with public needs, the general notions of the tax system, public finances, the role of the national, state and municipal tax system with the perspectives of evasion and tax avoidance from an ethical and regulatory approach. In these contents, the role of the university in the development of a tax culture and the analysis of didactic strategies for tax education should be highlighted.

It is important to emphasize that in order to achieve a development of the tax culture in university education, it is essential that teachers be trained to help them apply the teaching strategy to achieve this objective; as well as reversing the ignorance about the basic and

\footnotetext{
"Visión de Futuro" Año 19, Volumen No 26 N 1, Enero - Junio 2022 - Pág 22 - 37 URL de la Revista: http://visiondefuturo.fce.unam.edu.ar/index.php/visiondefuturo/index

URL del Documento: https://visiondefuturo.fce.unam.edu.ar/index.php/visiondefuturo/issue/view/22

ISSN 1668 - 8708 - Versión en Línea

E-mail: revistacientifica@fce.unam.edu.ar
} 
specific notions of the tax system of the countries. In this sense, the learning strategy of the tax culture must be supported by exposition activities of both teachers and students, where the discussion of the tax issue is promoted.

In this regard, strengthening the tax culture requires that the population have knowledge on the subject and understand the importance of fulfilling their tax responsibilities; which must be fed with timely and adequate information, which promotes the voluntary payment of its fiscal commitments and thus achieve a firm and sustainable collection in the medium and long terms, so that it is possible to comply with the duties of the State, mainly the Is satisfaction of citizens' needs.

In any case, education must become the means through which changes are generated in the thought, feeling and action of citizens, by stimulating the co-responsible participation of individuals to improve the quality of life, from which the need for a relationship between the education sector and the Tax Administration, which must be developed harmoniously, with respect for constitutional principles and an attitude attached to ethical values among the participating actors.

However, the goal that university education should pursue is to convert the tax culture into one of the fundamental bases of the modernization and development of countries, whose principles and objectives are shared by the various representative sectors of every society.

Undoubtedly, university education is presented as the most powerful means to transform the way of acting and thinking of individuals; And it must be one of the fundamental issues in productivity and competitiveness; But it is important to have feedback on the program content and the relevance of the study programs.

It should be noted that a true and authentic tax culture can only be created with awareness, responsibility, transparency and social vision that must be born and established in each of the Tax Administration units, through the principle of equity, in order to that can be extrapolated and assumed as a shared approach between the different actors of the legal-tax relationship, assuming awareness of their duties and responsibilities in a shared way and, based on the longed-for collective justice to which they constantly appeal.

For this purpose, the strategy to promote the tax culture must harmonize the ethical and the cultural, thereby contributing to the promotion of the culture of legality; In this sense, education plays an essential role in teaching tax culture.

Additionally, it is necessary to convert universities into a space for the construction of values in which the students who are being trained can make the most of the resources offered. In this way, they will achieve progress in the construction of matrices of singular and

\footnotetext{
"Visión de Futuro" Año 19, Volumen No 26 N 1, Enero - Junio 2022 - Pág 22 - 37

URL de la Revista: http://visiondefuturo.fce.unam.edu.ar/index.php/visiondefuturo/index

URL del Documento: https://visiondefuturo.fce.unam.edu.ar/index.php/visiondefuturo/issue/view/22

ISSN 1668 - 8708 - Versión en Línea

E-mail: revistacientifica@fce.unam.edu.ar
} 
personal values, guided by ideals of dignity, freedom and justice. The profile of a good university professional must include their training as a citizen and as a person; Although reality shows otherwise, this must be the ideal.

In this same sense, it is necessary to make alliances with other universities in order to strengthen the teaching updating, the academic training of the students, the attention to the taxpayers and the university social projection; This has a positive impact on the formation of a tax culture that indicates tax evasion as a harmful practice and that positively values compliance with tax obligations.

Within this framework, and in order to support the learning strategies of the tax culture, the participation of State agencies related to taxation and the corresponding universities is required; relying on private companies in the area in order to carry out exchanges in tax matters with universities, with which students would have the possibility of living together and learning about the efforts made by the private sector in tax matters, as well as the benefits obtained from tight management.

For this reason, to generate a tax culture in future professionals, it is advisable to implement strategies to insert in the curriculum design of higher education, subjects related to taxation, publicizing the benefits of paying taxes, thus promoting tax awareness, giving them a sense of responsibility and civility; since they will be the taxpayers and / or advisers of the future.

By virtue of the above, it is necessary to establish strategies for learning the tax culture in university education, indicating the need to apply:

- Pre-instructional strategies: aimed at preparing and alerting the student in relation to what to learn and how he should do it (activation of relevant previous knowledge and experiences) allowing him to place himself in the context of meaningful learning,

- Co-instructional: that support the curricular contents during the learning process; allowing to cover functions such as: detection of the main information; content conceptualization; delimitation of the organization, among others, and finally

- Post-instructional: which are presented after the content to be learned and allow the student to form a synthetic, integrative and even critical vision of the study material; such as interleaved questions, final summaries, concept maps, among others.

In which teachers are able to establish a feedback process with university students after carrying out the activities properly framed in the tax education of this educational sector.

Similarly, it is preponderant to develop university educational modules, focused on promoting entertaining reading about taxation, as well as stimulating the students themselves

\footnotetext{
"Visión de Futuro" Año 19, Volumen No 26 N 1, Enero - Junio 2022 - Pág 22 - 37

URL de la Revista: http://visiondefuturo.fce.unam.edu.ar/index.php/visiondefuturo/index

URL del Documento: https://visiondefuturo.fce.unam.edu.ar/index.php/visiondefuturo/issue/view/22

ISSN 1668 - 8708 - Versión en Línea

E-mail: revistacientifica@fce.unam.edu.ar
} 
to propose ideas to promote the generation of this knowledge; that serve to motivate reading on tax issues, new laws and the prevention of tax evasion.

Finally, one of the objectives that should be raised in tax education at the university level is to break this vicious circle and raise awareness that taxation is not only a legal obligation, but also a moral and ethical duty of each person before society. In addition, citizens must internalize that fulfilling this responsibility gives them the necessary authority to demand that the State make a correct and transparent use of public resources.

\section{REFERENCES}

Please refer to articles in Spanish Bibliography.

\section{BIBLIOGRAPHICAL ABSTRACT}

Please refer to articles Spanish Biographical abstract. 